\section{ScienceDirect}

Procedia Engineering 00 (2015) 000-000 \begin{tabular}{l}
$\overline{\text { Procedia }}$ \\
Engineering \\
\hline
\end{tabular}

www.elsevier.com/locate/procedia

\title{
Small buildings, big impacts: the role of small commercial building energy efficiency case studies in 2030 Districts
}

\author{
Elizabeth Barnes ${ }^{\mathrm{a}}$, Kristen Parrish ${ }^{\mathrm{a} *}$ \\ ${ }^{a}$ School of Sustainable Engineering and the Built Environment, Arizona State University, PO Box 873005, Tempe, AZ 85287, USA
}

\begin{abstract}
Small commercial buildings, or those comprising less than 50,000 square feet of floor area, make up $90 \%$ of the total number of buildings in the United States. Though these buildings currently account for less than $50 \%$ of total energy consumption in the U.S., this statistic is expected to change as larger commercial buildings become more efficient and thus account for a smaller percentage of commercial building energy consumption. This paper describes the efforts of a multi-organization collaboration and their demonstration partners in developing a library of case studies that promote and facilitate energy efficiency in the small commercial buildings market as well as a case study template that standardized the library. Case studies address five identified barriers to energy efficiency in the small commercial market, specifically, lack of: 1) access to centralized, comprehensive, and consistent information about how to achieve energy targets, 2) reasonably achievable energy targets, 3) access to tools that measure buildings' progress toward targets, 4) financial incentives that make the reduction effort attractive, and 5) effective models of how disparate stakeholders can collaborate in commercial centers to reach targets. The case study library can be organized by location, building type, project size, energy savings, end uses impacted, and retrofit measures. This paper discusses the process of developing the library and case study template. Finally, the paper presents next steps for the library and explores energy savings potential its widespread use.
\end{abstract}

(C) 2015 The Authors. Published by Elsevier Ltd.

Peer-review under responsibility of organizing committee of the International Conference on Sustainable Design, Engineering and Construction 2015.

Keywords: Small commercial buildings; building energy efficiency; case study

\footnotetext{
* Corresponding author. Tel.: 480-727-6363.

E-mail address: Kristen.Parrish@asu.edu
}

1877-7058 @ 2015 The Authors. Published by Elsevier Ltd.

Peer-review under responsibility of organizing committee of the International Conference on Sustainable Design, Engineering and Construction 2015. 


\section{Introduction}

The commercial building sector consumes nearly $40 \%$ of all US energy, which is more than the transportation or industry sectors $[1,2]$. With small commercial buildings accounting for $90 \%$ of the commercial building sector by count, and $47 \%$ of the commercial building sector's energy use, decreasing energy usage in small commercial buildings could make a major impact on energy in the US [3]. In fact, there could be as much as a 17\% reduction in total energy use if small commercial buildings were targeted for energy efficiency [3]. Through a multiorganization collaboration between the Lawrence Berkeley National Laboratory, Arizona State University, Architecture 2030, and 2030 Districts as Demonstration Partners, the team created resources specifically for small commercial building owners, operators, and designers looking to improve building energy efficiency. As part of this collaboration, the team created a case study template and library for energy efficiency projects in small commercial buildings in order to benefit and inform small commercial stakeholders interested in achieving building energy savings. This template and library leverages current case study databases, with useful search features along with practical visuals and figures, creating a succinct informational document that addresses barriers to energy efficiency identified for the small commercial sector.

Small commercial building sector energy use is concentrated into relatively few building types, making large energy savings possible with focus on a limited suite of building types. Energy use in these buildings is also very concentrated - over a quarter of total energy use goes towards lighting, thus in focusing on lighting efficiency in a few building types, large energy savings can be achieved. Figure 1 shows the full breakdown of energy end-use for the commercial sector [2]. Note that the gray section is a statistical adjustment.

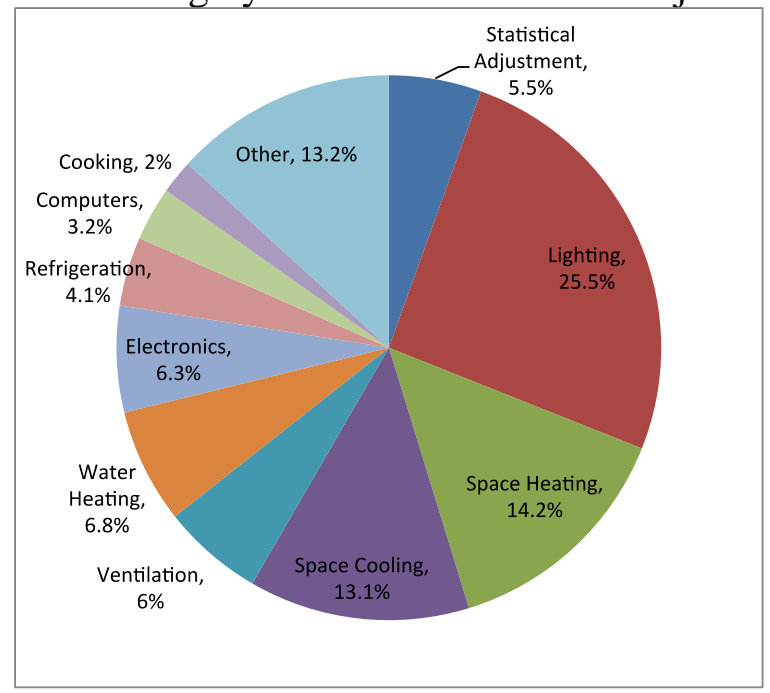

Fig. 1: Commercial energy end-use breakdown (data from [2])

This paper presents the work of a multi-organization project team participating in the U.S. Department of Energy's "Better Buildings: Commercial Energy Efficiency Solutions" program. Specifically, this team focuses on building Small Commercial 2030 District Programs \& Toolkits aimed at addressing barriers to energy efficiency in the small commercial building sector. The paper describes the small commercial buildings market, the multi-organizational team's composition and roles, and presents one tool in the Small Commercial Toolkit, case studies. Specifically, the paper presents the case study template and the case study library, each of which support energy efficiency projects in the 2030 Districts [4]. Note this paper presents work completed in year one of a two-year project period. 


\section{Project Team}

The Lawrence Berkeley National Laboratory (LBNL) and Architecture 2030 partnered to create a 2030 District toolkit for small commercial building energy efficiency, offering small commercial buildings resources to make participation in the popular Architecture 2030 Districts easier. Specifically, LBNL is the Lead and Technical Partner, while Architecture 2030 is the Deployment Partner. The team also works with four Demonstration Partners: the City of San Jose, the Seattle 2030 District, the Pittsburgh 2030 District, and the Cleveland 2030 District. Arizona State University (ASU) is a subcontractor of LBNL, and focused their efforts on developing a case study template and library. ASU engages the Demonstration Partners to collect case studies based on their projects. LBNL's primary responsibilities include developing the technical tools that each of the 2030 districts use, and project management. Architecture 2030 is responsible for developing the entire small commercial building energy efficiency program and toolkit, hosting the website, and coordinating all activities between the members of the project team and Demonstration Partners. The Demonstration Partners will pilot technical tools that the Lawrence Berkeley National Laboratory develops, implement energy efficiency measures within their districts, and submit baseline and post-retrofit energy data to the project team for use as program examples. Table 1 shows the responsibilities of each team member.

Table 1. Team member roles and responsibilities

\begin{tabular}{|c|c|c|}
\hline Team Member & Role & Responsibilities \\
\hline $\begin{array}{l}\text { Lawrence Berkeley National } \\
\text { Laboratory (LBNL) }\end{array}$ & $\begin{array}{l}\text { Lead Applicant, } \\
\text { Technical Partner }\end{array}$ & $\begin{array}{l}\text { - Technical tool development } \\
\text { - Project Management }\end{array}$ \\
\hline Architecture 2030 & Deployment Partner & $\begin{array}{l}\text { - } \quad \text { Deploy program and toolkit } \\
\text { - } \quad \text { Cost website } \\
\text { team and demonstration partners }\end{array}$ \\
\hline $\begin{array}{l}\text { City of San Jose, Seattle } 2030 \text { District, } \\
\text { Pittsburgh } 2030 \text { District, Cleveland } \\
2030 \text { District }\end{array}$ & $\begin{array}{l}\text { Demonstration } \\
\text { Partners }\end{array}$ & $\begin{array}{l}\text { - } \quad \text { Pilot technical tools } \\
\text { - } \quad \text { Implement efficiency measures } \\
\text { - } \text { efficiency baseline and post-retrofit } \\
\end{array}$ \\
\hline Arizona State University & $\begin{array}{l}\text { Subcontractor to } \\
\text { LBNL }\end{array}$ & $\begin{array}{l}\text { - Lead case study library and template } \\
\text { development } \\
\text { - Support Demonstration Partners and } \\
\text { LBNL while template is implemented } \\
\text { Work with Demonstration Partners to } \\
\text { produce case studies from pilot projects }\end{array}$ \\
\hline
\end{tabular}

\section{The Small Commercial Buildings Market}

With small commercial buildings making up $90 \%$ of the commercial building sector by count, this sector represents a great potential for energy savings in commercial buildings $[1,3,5]$. However, barriers exist that prevent small building owners and managers from improving energy consumption in comparison to large commercial building owners and managers; this is mainly due to the lack of capital and resources available to owners, and the different priorities that small businesses have compared to large businesses. Small commercial building owners, most often individual or family entities, do not have the time or money to focus on improving energy efficiency while also maintaining a profitable business. Toolkits and management programs are often geared towards large building owners, who can hire out a professional team to manage 
these energy projects, whereas small building owners may need resources that require less technical expertise and time to implement, e.g., user-friendly "checklists" rather than a detailed sequence of operations.

The small commercial market is also made up of very different demographics in terms of ownership, management, use of building, and physical building traits. Figure 2 illustrates a breakdown of ownership and management in the small building market, based on a survey conducted by the National Trust for Historic Preservation [3, 6].

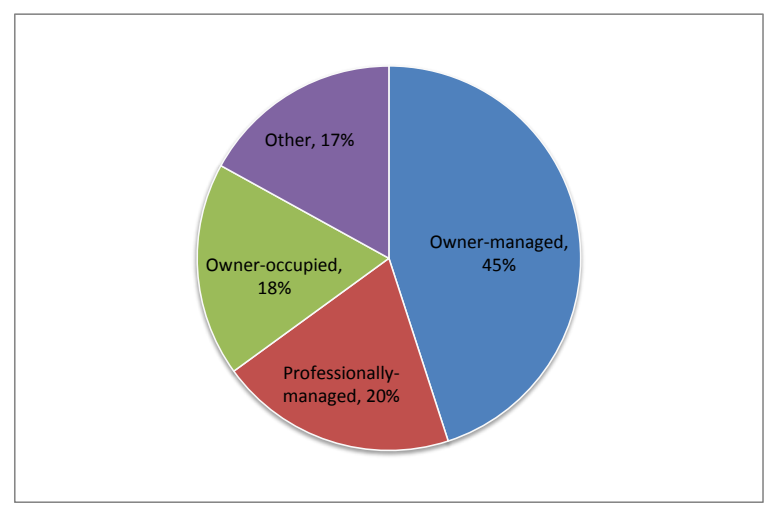

Fig. 2: Small Commercial Buildings Ownership and Management (data from $[3,6])$

Most buildings fall into the category of owner- or professionally- managed, suggesting they are tenant-occupied. The large portion of small commercial buildings that fall into the category of "owner-managed" is in contrast to large commercial buildings that are often professionally managed. In the case of small commercial buildings, owners are more often the decision-makers, and also tend to be more concerned about convenience and business identity than energy and they may lack the time, money, and knowledge to make decisions based on other criteria.

The physical characteristics of buildings in the small commercial sector also vary greatly - not only compared to large commercial buildings, but also within the market itself. The small commercial buildings market comprises multiple building types for different businesses in the market, including offices, mixed-use main street buildings, retail space, and food centers. Therefore, each building has specific needs, which makes it difficult to develop one-size-fits-all toolkits or other resources for energy efficiency. Luckily, a few building types account for a majority of the energy use in the small commercial sector, thus allowing for concentration on those specific types that will lead to energy reduction. Namely, these include Food Service, Main Street (attached, multi-use), and Strip Malls.

\section{2030 Districts}

Architecture 2030 is a non-profit focused on two primary objectives: reduce fossil fuel consumption and greenhouse gas emissions within the built environment, and develop an adaptive, resilient built environment [7]. Architecture 2030 focuses on the building sector in particular since building operations and construction make up about $48 \%$ of US energy consumption, $75 \%$ of US electricity consumption, and $45 \%$ of $\mathrm{US} \mathrm{CO}_{2}$ emissions [8].

2030 Districts is an Architecture 2030 initiative created to reduce energy, water, and vehicle emissions in existing and new buildings and infrastructure, which is based on Architecture 2030's 2030 Challenge for Planning [4]. This initiative brings together property owners and managers, local governments, businesses, and community stakeholders with the idea that public 
and private partnerships within specific districts (typically downtown or urban core areas) can reach these reduction goals through collaboration and shared resources. This partnership aligns public and private sector shareholders by providing the same metrics and tools to both in order to effectively reach goals, while also complementing any existing initiatives. Some of the tools available to private sector building owners and managers are: building performance assessments, benchmarking, and project scoping and feasibility [9]. However, the current resources available to private stakeholders are general and consistently cater to the large commercial building sector.

There are 12 Established Districts: Seattle, Cleveland, Pittsburgh, Los Angeles, Denver, Stamford, San Francisco, Dallas, Toronto, Grand Rapids, San Antonio, and Albuquerque. These Established Districts have a combined 269 million square feet of properties committed to the 2030 Districts reduction plan. There are also additional Emerging Districts: Ann Arbor, Detroit, Ithaca, and Portland. The Seattle, Cleveland, and Pittsburgh 2030 Districts are part of the pilot program for the Small Commercial Toolkit, and are also the top three districts for most committed square feet of properties with Seattle committing 45 million square feet, Cleveland committing 37 million square feet, and Pittsburgh committing the most at 66 million square feet [9].

New and existing buildings and infrastructure within the 10 Established 2030 Districts are held to different energy, water, and $\mathrm{CO}_{2} \mathrm{e}$ reduction standards, with new buildings and infrastructure required to have a higher percent reduction by 2030. Table 2 summarizes the reduction goals of the 2030 Districts [9].

Table 2: 2030 Districts reduction goals

\begin{tabular}{|c|c|c|}
\hline & New buildings and infrastructure & Existing buildings and infrastructure \\
\hline Energy Use & $\begin{array}{l}70 \% \text { reduction below national } \\
\text { average, with incremental targets, } \\
\text { reaching carbon neutral by } 2030\end{array}$ & $\begin{array}{c}\text { Minimum of } 20 \% \text { reduction below } \\
\text { national average by } 2020 \text { with incremental } \\
\text { targets, reaching } 50 \% \text { reduction by } 2030\end{array}$ \\
\hline Water Use & $\begin{array}{l}\text { Immediate } 50 \% \text { reduction below } \\
\text { current district average }\end{array}$ & $\begin{array}{l}\text { Minimum of } 20 \% \text { reduction below the } \\
\text { district average by } 2020 \text {, with incremental } \\
\text { targets, reaching } 50 \% \text { reduction by } 2030\end{array}$ \\
\hline $\mathrm{CO}_{2} \mathrm{e}$ auto and freight & $\begin{array}{l}\text { Immediate } 50 \% \text { reduction below } \\
\text { district average }\end{array}$ & $\begin{array}{l}\text { Minimum of } 20 \% \text { reduction below } 2020 \\
\text { with incremental targets, reaching } 50 \% \\
\text { reduction by } 2030\end{array}$ \\
\hline
\end{tabular}

However, the 2030 Districts tools are not geared towards meeting the needs of a small commercial building owner interested in energy use and cost reduction. In the Seattle 2030 District, for instance, more than $66 \%$ of buildings are small commercial, of which $32.5 \%$ are above the median energy consumption in their category. Meanwhile, large commercial buildings in the Seattle 2030 district are operating $45 \%$ better than the median energy consumption in their category. The large commercial market within the 2030 Districts is very engaged, and has an average ENERGY STAR score of 91.4 EUI, while the small commercial market has an average of 63.6 EUI. (Note an ENERGY STAR score of 75 qualifies a building as ENERGY STAR certified [10]). Within the Established Districts, large commercial buildings are faring better with energy use and cost reduction due to the higher number of resources available and the ability to hire a professional building manager to reduce energy consumption. Creation of this toolkit will allow small commercial building owners and managers to work effectively with the public sector to reach reduction goals. 


\section{Leveraging and Sharing the Success of the 2030 District Model}

With the success of large commercial building energy reduction resources within the 2030 Districts, this toolkit includes similar tools and resources, but are more detailed and more userfriendly to accommodate the small commercial building owners' specific needs. The most important design aspect is including both technical and non-technical tools since both will address the needs of small building owners lacking knowledge in the subject area. To facilitate this, the project team developed a 2030 web portal, www.2030districts.org, that allows 2030 District members to access technical and non-technical tools that support achieving 2030 District energy, carbon, and water goals. Technical tools allow building owners to view specific calculations and results related to energy and energy cost reduction, like HVAC and lighting efficiency, and options recommended for their specific building. The non-technical tools exhibit the possibilities within energy and energy cost reduction through existing case studies in the case study library, financing, and resource information. By including case studies, users are able to compare lessons learned, costs, and benefits of energy efficiency for similar buildings. Case studies range from light to deep retrofits, showing users a wide range of possibilities for their own project.

While the authors focused almost solely on the design of the case study template and library, the design of the toolkit had to stay consist between the technical and non-technical tools. The same design ideas of simplicity and user-friendliness for the case study template were applied to the case study library and technical tools. The case study library has numerous search terms located at the top of the page, similar to the questions for the user during the Guide Me - General Information, thus continuing the user-friendliness of the library. The links to the case studies themselves are straight-forward and simple, shown with a picture and minimal information about the building: name, building type, location, and footprint (in square feet). By including both the search terms at the top, and the information included in the case study link, users can use either method to find case studies to fit their needs. The same idea of the case study link including a picture and minimal information was also used in the design of the links to the tools. Each tool has an illustration related to the tool (e.g., a light bulb for the lighting retrofit tool), and a short paragraph describing the tool.

User-friendliness is not only accomplished through the simple aesthetics, but also through the Guide Me process for the technical and non-technical tools. The Guide Me process for both involves questions about the project, ranging from general information to more technical information about the building. By asking questions about the project, the toolkit can give case study recommendations based on geographic data and technical tool recommendations based on the equipment in the building and renovation details. Case study recommendations are based on tags that are associated with each case study in the library. Tagging the case studies is done manually, and covers numerous search options within each search term for the case study library. Future users can also select as many tags for their case study as they choose, thus broadening the number of search options available in the case study library. The Guide Me process walks portal users through the process of researching and implementing energy reduction measures for their building in a format that does not require prior experience with energy efficiency. Including a guiding process was a key part of the design of the toolkit for both the technical and nontechnical tools since it addresses the needs of small commercial building stakeholders.

Incorporating both a guiding process and direct links to the case study library and technical tools ensures users with any level of experience are able to effectively use the tools.

\section{Case Study Template}

In order to create an effective and usable case study template, the authors reviewed case studies from related databases. Case study databases reviewed include those of the New 
Buildings Institute [11], Architecture 2030 [12], the 2030 Palette [13], Rocky Mountain Institute's Retrofit Depot [14], and the Department of Energy's Commercial Buildings Resource Database [15]. The authors assessed the following case study attributes in each of the databases: visuals and/or figures, search features, consistency, amount of information available, highlighting and/or summarizing of data, legibility, ease of online and print reading, project photos, company or firm branding. Table 3 presents an excerpt of the authors' assessment of case studies reviewed.

Table 3: Subset of research findings from existing databases

\begin{tabular}{|c|c|c|c|c|c|c|}
\hline Necessary Feature & $\begin{array}{l}\text { Palette case } \\
\text { studies } \\
(\mathrm{n}=26)\end{array}$ & $\begin{array}{l}\text { Seattle } \\
2030 \text { case } \\
\text { studies } \\
(\mathrm{n}=23)\end{array}$ & $\begin{array}{l}\text { NBI case } \\
\text { studies } \\
(n=53)\end{array}$ & $\begin{array}{l}\text { Architecture } 2030 \\
\text { case studies } \\
(n=27)\end{array}$ & $\begin{array}{c}\text { DOE } \\
\text { Commercial } \\
\text { Buildings } \\
\text { Resource } \\
\text { Database } \\
(\mathrm{n}=53) \\
\end{array}$ & $\begin{array}{l}\text { High } \\
\text { Performance } \\
\text { Buildings } \\
\text { Database } \\
(\mathrm{n}=20)\end{array}$ \\
\hline $\begin{array}{l}\text { Visuals and } \\
\text { Figures }\end{array}$ & $\begin{array}{l}\text { Yes, but } \\
\text { only a few } \\
\text { and not } \\
\text { very } \\
\text { detailed. }\end{array}$ & $\begin{array}{l}\text { No visuals } \\
\text { or figures. }\end{array}$ & $\begin{array}{l}\text { Yes, but } \\
\text { slightly too } \\
\text { many } \\
\text { words. }\end{array}$ & $\begin{array}{c}\text { No figures or } \\
\text { visuals available } \\
\text { on the } 2030 \\
\text { website, but } \\
\text { available through } \\
\text { links. }\end{array}$ & $\begin{array}{l}\text { Yes, many } \\
\text { visuals and } \\
\text { figures. }\end{array}$ & $\begin{array}{c}\text { Some tables } \\
\text { shown, but } \\
\text { overall not } \\
\text { many. }\end{array}$ \\
\hline Consistent Format & $\begin{array}{l}\text { Yes, there } \\
\text { is a } \\
\text { consistent } \\
\text { format. }\end{array}$ & $\begin{array}{l}\text { Yes, } \\
\text { consistent } \\
\text { format. }\end{array}$ & $\begin{array}{l}\text { Yes, all } \\
\text { have } \\
\text { similar } \\
\text { format. }\end{array}$ & $\begin{array}{c}\text { Data on the page is } \\
\text { consistent, but } \\
\text { linked data not all } \\
\text { same. }\end{array}$ & $\begin{array}{l}\text { All have } \\
\text { similar format, } \\
\text { not exact. }\end{array}$ & $\begin{array}{l}\text { Yes, all } \\
\text { have same } \\
\text { format. }\end{array}$ \\
\hline Search Features & $\begin{array}{c}\text { Yes, there } \\
\text { is a column } \\
\text { with } \\
\text { keywords }\end{array}$ & $\begin{array}{l}\text { No search } \\
\text { features. }\end{array}$ & $\begin{array}{l}\text { No search } \\
\text { features. }\end{array}$ & $\begin{array}{l}\text { Yes, extensive } \\
\text { search features. }\end{array}$ & $\begin{array}{c}\text { Yes, } \\
\text { searchable } \\
\text { with numerous } \\
\text { filtering } \\
\text { options. } \\
\end{array}$ & $\begin{array}{l}\text { Yes, many } \\
\text { search } \\
\text { features. }\end{array}$ \\
\hline $\begin{array}{l}\text { Entire case study } \\
\text { available, no links }\end{array}$ & $\begin{array}{c}\text { Yes, entire } \\
\text { case study } \\
\text { is } \\
\text { available, } \\
\text { but not } \\
\text { specific. } \\
\end{array}$ & $\begin{array}{l}\text { There are } \\
\text { no links, } \\
\text { but not } \\
\text { specific. }\end{array}$ & $\begin{array}{l}\text { Yes, entire } \\
\text { case study } \\
\text { available. }\end{array}$ & $\begin{array}{l}\text { No, case studies } \\
\text { are linked and } \\
\text { some links don't } \\
\text { work. }\end{array}$ & $\begin{array}{l}\text { Yes, entire } \\
\text { case study } \\
\text { available. }\end{array}$ & $\begin{array}{l}\text { The entire } \\
\text { case study is } \\
\text { available, } \\
\text { but is } \\
\text { separated }\end{array}$ \\
\hline $\begin{array}{c}\text { Features } \\
\text { summarizing data, } \\
\text { or highlighting } \\
\text { important data } \\
\end{array}$ & No features & $\begin{array}{l}\text { Yes, } \\
\text { column on } \\
\text { side }\end{array}$ & $\begin{array}{c}\text { Yes, } \\
\text { features } \\
\text { and } \\
\text { summary }\end{array}$ & $\begin{array}{c}\text { Yes, the only } \\
\text { information } \\
\text { available is a } \\
\text { summary of data. }\end{array}$ & $\begin{array}{c}\text { Yes, } \\
\text { summarization } \\
\text { of important } \\
\text { stats and data. }\end{array}$ & $\begin{array}{c}\text { There is an } \\
\text { overview at } \\
\text { the } \\
\text { beginning. }\end{array}$ \\
\hline $\begin{array}{l}\text { Legible, modern, } \\
\text { minimalist, easy to } \\
\text { read }\end{array}$ & $\begin{array}{l}\text { Yes, but } \\
\text { more } \\
\text { casual than } \\
\text { technical. }\end{array}$ & $\begin{array}{c}\text { Not } \\
\text { modern, } \\
\text { but } \\
\text { legible. }\end{array}$ & $\begin{array}{l}\text { Yes, very } \\
\text { legible, } \\
\text { modern. }\end{array}$ & $\begin{array}{l}\text { Unanswerable. } \\
\text { Many case studies } \\
\text { are not accessible. }\end{array}$ & $\begin{array}{c}\text { Yes, very } \\
\text { legible and } \\
\text { easy to read. }\end{array}$ & $\begin{array}{c}\text { Legible, but } \\
\text { organization } \\
\text { could be } \\
\text { better. } \\
\end{array}$ \\
\hline $\begin{array}{l}\text { Pictures/renderings } \\
\text { of site }\end{array}$ & $\begin{array}{l}\text { Yes, there } \\
\text { are pictures } \\
\text { of the } \\
\text { building(s). }\end{array}$ & $\begin{array}{l}\text { Yes, there } \\
\text { are } \\
\text { pictures of } \\
\text { the site. }\end{array}$ & $\begin{array}{c}\text { Yes, } \\
\text { picture of } \\
\text { completed } \\
\text { building. }\end{array}$ & $\begin{array}{l}\text { Yes, there are } \\
\text { pictures of the } \\
\text { building. }\end{array}$ & $\begin{array}{l}\text { Yes, pictures } \\
\text { of completed } \\
\text { building. }\end{array}$ & $\begin{array}{l}\text { Yes, } \\
\text { "Images" } \\
\text { section. }\end{array}$ \\
\hline
\end{tabular}




\begin{tabular}{|c|c|c|c|c|c|c|}
\hline $\begin{array}{c}\text { Company/Firm } \\
\text { branding }\end{array}$ & $\begin{array}{c}\text { No, just } \\
\text { branding } \\
\text { for Palette } \\
\text { blog }\end{array}$ & $\begin{array}{c}\text { Building } \\
\text { owner is } \\
\text { mentioned }\end{array}$ & $\begin{array}{c}\text { Owner is } \\
\text { mentioned, } \\
\text { branding } \\
\text { for NBI }\end{array}$ & $\begin{array}{c}\text { Architect/Engineer } \\
\text { and Owner is } \\
\text { mentioned }\end{array}$ & $\begin{array}{c}\text { No, most } \\
\text { branding it for } \\
\text { DOE }\end{array}$ & $\begin{array}{c}\text { Owner and } \\
\text { project team } \\
\text { mentioned. }\end{array}$ \\
\hline Easy to print & $\begin{array}{c}\text { No, do not } \\
\text { print well. }\end{array}$ & $\begin{array}{c}\text { Prints } \\
\text { well } \\
\text { formatted } \\
\text { as PDF }\end{array}$ & $\begin{array}{c}\text { Prints well } \\
\text { formatted } \\
\text { as a PDF }\end{array}$ & $\begin{array}{c}\text { No, do not print } \\
\text { well. }\end{array}$ & $\begin{array}{c}\text { Yes, print well } \\
\text { - formatted as } \\
\text { PDF }\end{array}$ & $\begin{array}{c}\text { Only print } \\
\text { one section } \\
\text { at a time, } \\
\text { prints well. }\end{array}$ \\
\hline
\end{tabular}

Based on the research findings, the authors determined the case study template should be a user-friendly web form, with all necessary information legible and straightforward. The template is a fillable web form that can easily be printed on two pages, with the first page providing quick project highlights and the second page providing more detail. Figure 3 shows the first page of an existing case study formatted with the case study template from the 2030 Districts website. The top of the first page lists the 2030 District or Demonstration Partner associated with the project, the title of the project, and associated energy savings as both a percentage of consumption reduced and as a cost savings. The energy savings is prominent at the top, as research indicated energy savings would be a motivating factor for a user deciding which case studies (s)he may be able to replicate. The left-hand column provides a summary and photo of the project, while the right hand column presents a quote about the project, and the top decision criteria for implementing the project. The decision criteria table covers the reasons why the owner pursued the energy retrofit project. At the bottom of the first page, there is a table summarizing useful, but basic statistics on the project like building type, location, and cost. The first page also includes a table presenting challenges or lessons learned from the project, and a space for owner or tenant contact information. The challenges or lessons learned table comprises the issues the project team dealt with, how they dealt with them, if they succeeded or not, and what they would do in the future. This first page covers all of the most important aspects of the projects, while being succinct and visually appealing. All information on the first page is considered "required." The user inputs pre- and post-retrofit energy consumption and utility bill costs, and the template automatically calculates the reductions of various energy forms (e.g., gas, steam). 


\section{CASE STUDY - DEEP ENERGY SAVINGS IN EXISTING BUILDINGS - THE LOVEJOY BUILDING}

\section{Project Summary}

Originally built in 1910 as the stables for the Marshall-Wells Hardware Company, the Lovejoy Building is the home of Opsis, an architectural design firm practicing sustainable design.

The building is located in Northwest Portland in an area known as "Slabtown," formerly home to early lumber mill workers. The owner architects purchased and renovated the historic building in 2003 to house their growing business and to provide ground-floor office lease space and second floor offices for their firm. Retrofit of the existing load-bearing brick structure required a major seismic upgrade. The architects used this as an opportunity for an integrated response to advanced structural upgrades, enhanced user thermal comfort and improved energy savings. Opsis wanted to use the building to experience and demonstrate the technologies and practices it promotes with clients. Creating an open, comfortable and resource-efficient office space was a priority; incorporating upgraded efficiency features was considered an integral part of the normal project budget. The building's actual energy use is $40 \mathrm{kBtu} / \mathrm{sf} / \mathrm{yr}, 57 \%$ better than the average for office buildings in the U.S. The building also qualified for the U.S. Green Building Council's Leadership in Energy and Environment (LEED) certification at a Gold level in 2006.

\section{Project Stats}

Location:

Building Type:

Ownership Model:

Project Implementer:

Project Size

Total Energy Savings (KW):

Energy Cost Savings (\$):

Energy Savings (\$) vs. preretrofit use:

Retrofit Project Cost (\$):

Project Financing Type:

Simple Payback (Years):

Completion Date:
Portland, OR

Office

Owner Occupied

Owner/Owner's Agent

$20000 \mathrm{sq} \mathrm{ft}$

310,716

25,510

$57 \%$

\section{$2,300,000$}

Real Estate Backed Loan

90 years

2004

\section{Fuel Types and Savings}

\begin{tabular}{lll|} 
Electricity & $\$ 25,510$ & $57 \%$ \\
Steam & $\$ 0$ & $0 \%$ \\
Natural Gas & $\$ 0$ & $0 \%$
\end{tabular}

Natural Gas $\$ 0$

"There can be a disconnect for architects to understand the real world and what it means to be the one to write the check. We wanted to 'walk the talk' as proponents of green building design."

James Meyer

Owner

\section{Top Decision Criteria}

\#1 Corporate Values

The goal of the project was to create a building that aligned with the culture and professional objectives of Opsis.

\section{\#2 Occupant Comfort}

An in-floor hydronic heating and cooling system was chosen to optimize open space as well as to provide greater individual thermal comfort.

\section{Challenges/Lesson Learned}

Heating and cooling system

The most innovative aspect of their building is the in-floor hydronic heating and cooling system.

Incorporating energy-efficiency

Opsis wanted to incorporate as many energy-efficient measures into the building as possible.

\section{Contact Info}

Opsis Architecture - -

Fig. 3: First page of case study template populated with an existing case study - 2030 Districts

Figure 4 shows the second page of an existing case study utilizing the case study template from the 2030 Districts website. The second page goes into further detail about the project, but maintains a focus on information that helps future users replicate the project. This page presents 
specific retrofit measures implemented, with descriptions of these measures and associated end uses. This page includes space for user-defined input, e.g., photos or videos, if applicable, and a text box for including additional information. This page includes a table of retrofit measures considered, but not implemented, with a description of that decision. A recommendation quote is also shown on the second page, which is usually related to challenges the project team faced, or a process that went particularly well for the team. Finally, this page includes references for those looking to learn more about the project. All second-page content is considered non-essential, but important to those interested in learning more about the project. This page also describes retrofit measures implemented; it is one of the largest sections on the page.

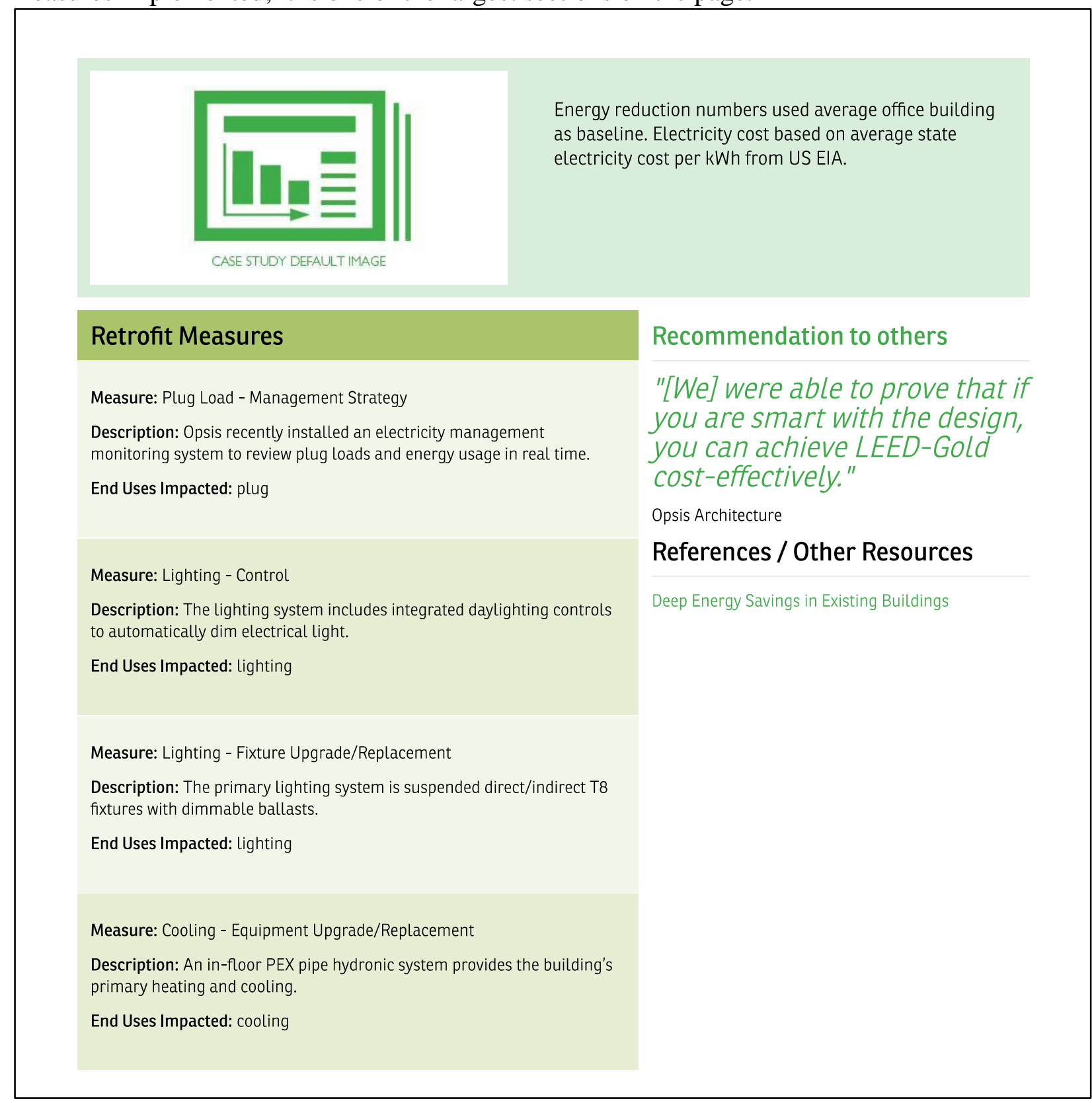

Fig. 4: Second page of case study template with example case study - 2030 Districts 


\section{Case Study Library}

At the time of this publication, the case study template is complete and the case study library includes existing case studies from other databases. The case study library comprises projects using the case study template, and related search terms as discussed earlier in this paper. Users can filter case studies by: location, building type, ownership type, project size, retrofit measures, end uses impacted, decision criteria, energy savings, and fuel type used (Table 4). Figure 5 shows the existing case study library interface on the 2030 Districts website, including the available search options. Some of the same search criteria are used as the questions in the Guide Me - General Information process, as shown in Figure 6. These options are based on tags associated with each existing case study.

Table 4: Case study library search options available for each search term

\begin{tabular}{|c|c|c|c|c|c|c|c|c|}
\hline Location & $\begin{array}{c}\text { Ownership } \\
\text { Type }\end{array}$ & $\begin{array}{l}\text { Decision } \\
\text { Criteria }\end{array}$ & $\begin{array}{c}\text { Energy } \\
\text { Savings } \\
(\%)\end{array}$ & $\begin{array}{l}\text { Project } \\
\text { Size } \\
(\mathrm{SF})\end{array}$ & $\begin{array}{l}\text { Building } \\
\text { Type }\end{array}$ & $\begin{array}{l}\text { End Uses } \\
\text { Impacted }\end{array}$ & $\begin{array}{l}\text { Retrofit } \\
\text { Measure }\end{array}$ & $\begin{array}{l}\text { Fuel } \\
\text { Type } \\
\text { Used }\end{array}$ \\
\hline \multirow[t]{9}{*}{ State } & $\begin{array}{c}\text { Leased/Rented } \\
\text { - Owner } \\
\text { Managed }\end{array}$ & Corporate & Min & Min & Education & Lighting & $\begin{array}{c}\text { Lighting } \\
\text { control }\end{array}$ & Electric \\
\hline & $\begin{array}{c}\text { Owner } \\
\text { Occupied }\end{array}$ & Savings & Max & Max & Food Sales & Heating & $\begin{array}{l}\text { Lighting } \\
\text { fixture }\end{array}$ & Steam \\
\hline & & $\begin{array}{l}\text { Family } \\
\text { History }\end{array}$ & & & Office & Vent & Heating & Gas \\
\hline & & Comfort & & & $\begin{array}{c}\text { Public } \\
\text { Assembly }\end{array}$ & Plug & Vent control & \\
\hline & & Operational & & & Mercantile & Cooling & $\begin{array}{c}\text { Vent } \\
\text { insulation }\end{array}$ & \\
\hline & & Policy & & & & & $\begin{array}{c}\text { Plug } \\
\text { equipment }\end{array}$ & \\
\hline & & $\begin{array}{l}\text { Goal of } \\
\text { Zero Net } \\
\text { Energy }\end{array}$ & & & & & $\begin{array}{l}\text { Cooling } \\
\text { equipment }\end{array}$ & \\
\hline & & & & & & & $\begin{array}{c}\text { Vent } \\
\text { opening }\end{array}$ & \\
\hline & & & & & & & $\begin{array}{c}\text { Plug } \\
\text { management }\end{array}$ & \\
\hline
\end{tabular}


2030

DISTRICTS

2030 DISTRICTS NEWSLETTER

Email Address *

First Name *

\section{CASE STUDIES}

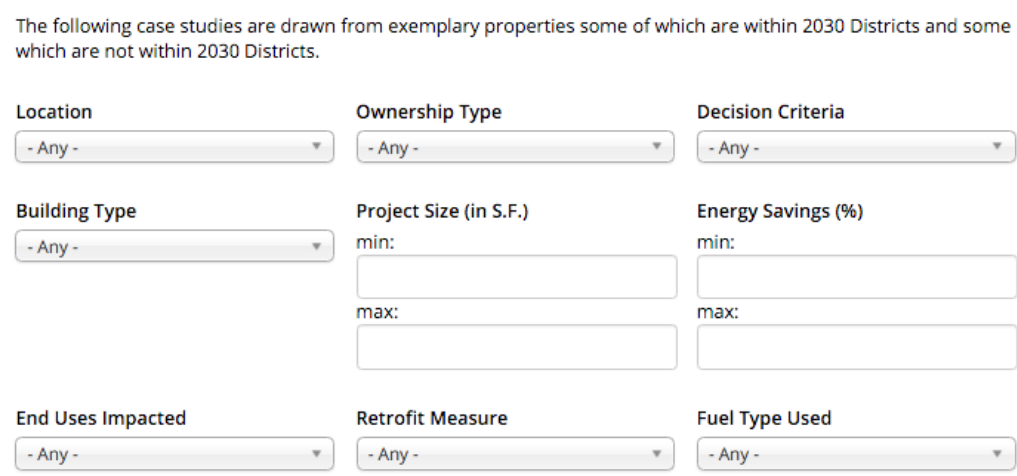

๑ (0) Register | Login

about districts toolkits marketplace news contact us SEARCH
Submit

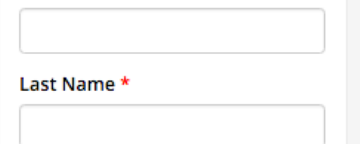

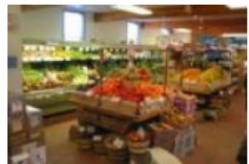

The Renovation and Expansion of People's Food Co-op

Building Type: Food Sales

Location: Portland, OR

Size SF: $5,400.00$

Figure 5: Case study library and search options

\section{Guide Me Process on the 2030 Districts Web Portal}

Users can either go directly to the case study library and use the search options detailed above to narrow their search, or they can use the Guide Me process. During the Guide Me process, the user must input basic information about their building like climate zone, ownership, decision criteria, building type, and fuel types along with questions about the project itself. These questions are very similar to the search terms available in the case study library, however there are more options available because this process is not dependent on the tagging of case studies to add options, but instead are based off of research from other similar databases. Only the most common options from this research are included in both the search options and the Guide $\mathrm{Me}$ process. After entering the necessary project information, three to five case studies based on the geographic location of the building are recommended, with the option to go to the entire case study library if the user is interested in researching more case studies outside of their location. These recommended case studies are saved for future use by the user, and can be accessed through a button in the left column of the page marked "Recommendations". The existing user interface for the Guide Me - General Information process is shown in Figure 6. 
2030

D I S T R I C T S
๑) 0

ABOUT DISTRICTS TOOLKITS MARKETPLACE NEWS CONTACT US
Welcome, casestudy | My Projects | L SEARCH
TOOLKITS

Small Commercial Toolkit

District Formation

Member Resources

Small Commercial

Project Financing

District Operations

Outreach \& Communications

District Funding

Performance Metrics

\section{FAKEPROJECT}

PROJECT TOOLS

\section{PRONECT HOME}

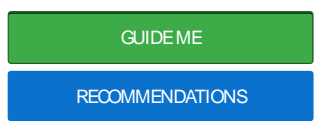

TECHNICAL TOOLS

RESULTSDASHBOARD

\section{General}

Climate Zone

5A Cool-Humid

Ownership Type

N/A

Leased/Rent - Owner Managed

Owner Occupied

What is your most important criteria in decision making for retro ts? (check all that apply)

$\square$ Asset Value

$\square$ Corporate Values

$\square$ Energy Cost Savings

$\square$ Occupant Comfort

$\square$ Operational

$\bigcirc$ Policy

$\square$ Rebates and Incentives

$\square$ System Failure

$\square$ Tenant Retention

What is your building type? (check all that apply)

$\square$ Education

$\square$ Food Sales

$\square$ Food Service

$\square$ Healthcare (Outpatient)

$\square$ Lodging

$\square$ ce

$\square$ Public Assembly

$\square$ Public Order and Safety

$\square$ Religious

$\square$ Service

$\square$ Warehouse and Storage

$\square$ Mercantile

$\square$ Multi-Family Residential

What fuel types does your building use? (check all that apply)

$$
\begin{aligned}
& \square \text { electric } \\
& \square \text { steam } \\
& \square \text { gas } \\
& \square \text { oil } \\
& \square \text { other }
\end{aligned}
$$

Figure 6: Guide $\mathrm{Me}$ - General Information process 
Over time, the case study library will expand and include Demonstration Partner projects as well as other small commercial building energy retrofit projects completed in the 2030 Districts. This library serves as a record of Demonstration Partner projects and provides evidence for small commercial building stakeholders that energy and energy cost savings are achievable. Moreover, the case study library includes specific recommendations about how to make energy efficiency projects successful in small commercial buildings. The case study library also documents the Demonstration Partners' experiences with other tools in the small commercial toolkit. As the Demonstration Partners report energy savings goals, strategies, etc. and also implement retrofit projects, ASU helped the Partners document the retrofit process to create case studies of their projects.

\section{Small Commercial Toolkit}

In addition to the case study library, the Small Commercial Toolkit includes HVAC, lighting, plug load, and whole building energy calculators, an Energy Management Process, and financing information. The calculators estimate energy and energy cost savings based on different efficiency levels, while the Energy Management Process contains information for HVAC contractors, and the financing information explains cost, funding options, and savings predictions for various energy efficiency investments. Figure 7 shows the Small Commercial Toolkit interface on the 2030 District web portal.
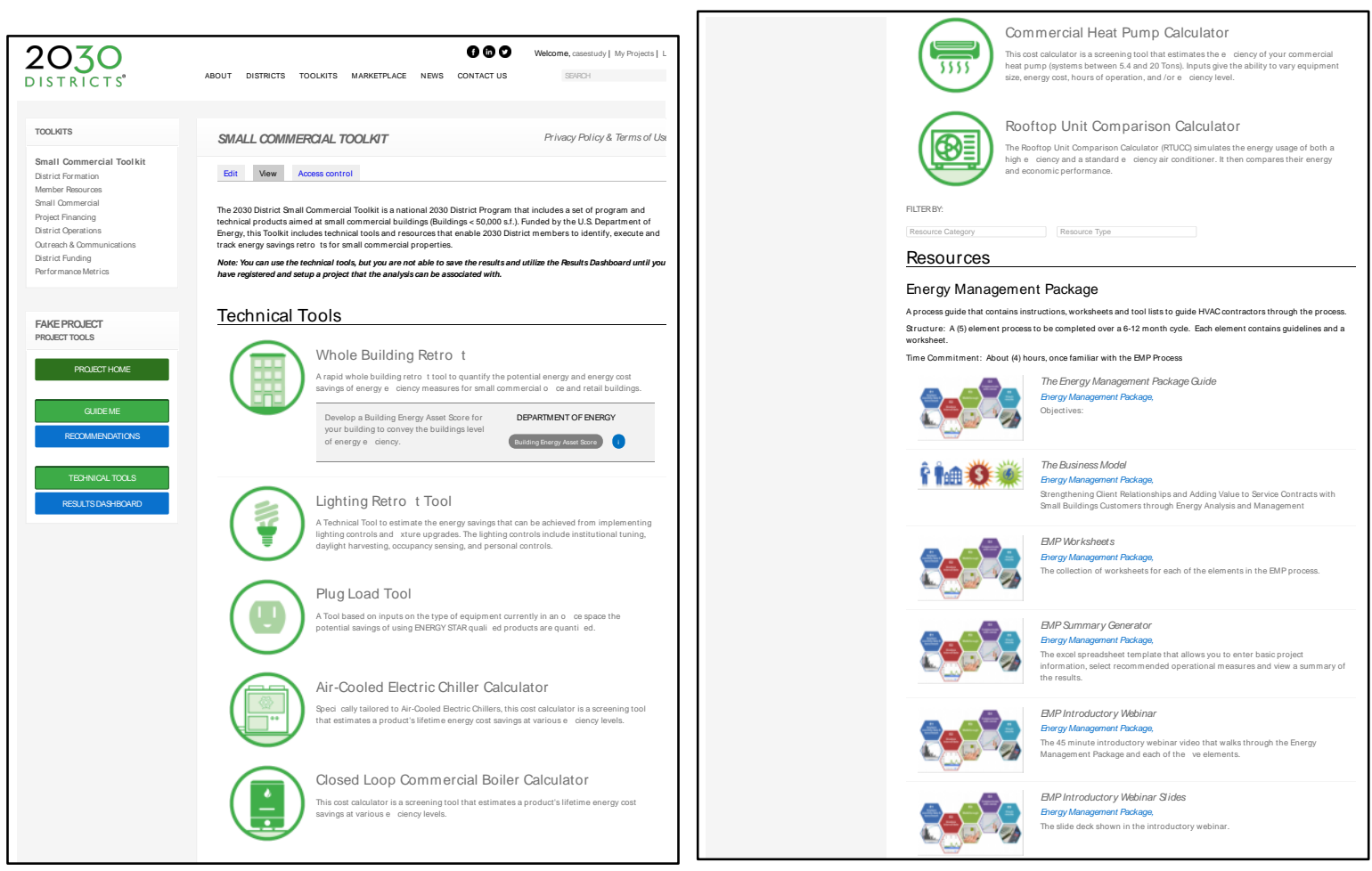


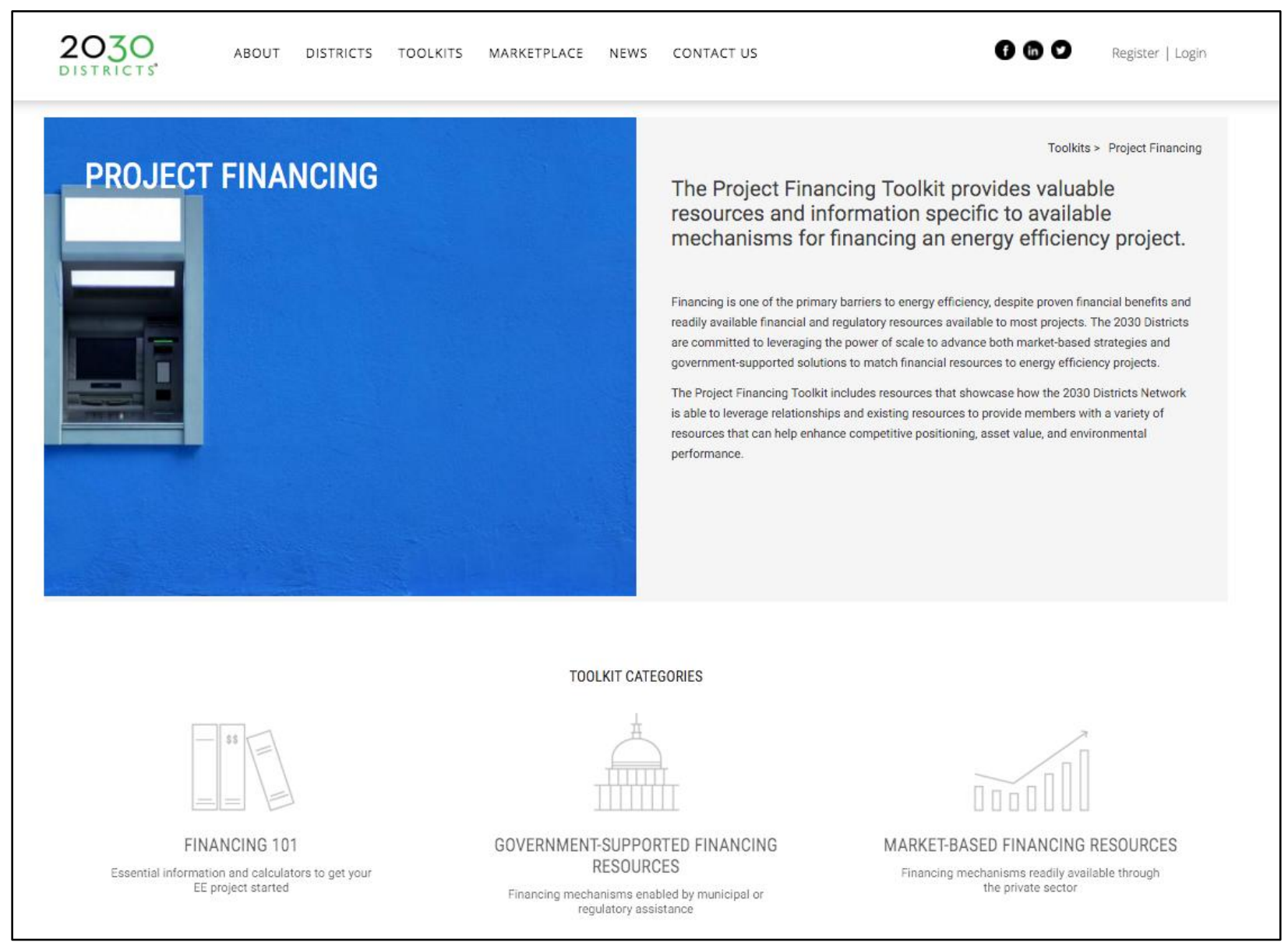

Figure 7: Screenshots of the interfaces for the technical tools and resources of the Small Commercial Toolkit (top);

Project Financing Toolkit (bottom)

There are two ways to reach these tools - through the Guide Me process, or going directly to the tools. The Guide Me process is geared towards those who are new to the process of using energy efficiency tools and need additional help on what tools to use. This process leads the user to the suggested technical tools for their project based on project information, like energy use data source, and the type of HVAC machinery used in the building as well as financing recommendations. Climate zone is also a major deciding factor for recommended tools and energy efficiency measures. Based on the information provided about the project at the beginning of the Guide Me process, the climate zone of the project is determined and associated with specific energy efficiency measures. This ensures that users with projects in California are not given the same recommendations as users with projects in the Midwest since energy use, electricity cost, and equipment differ greatly between the two locations due to different climates.

The tool, financing, and resource recommendations are stored under Recommendations in the left column, while the results from using the technical tools will be compiled on a separate Results page for the user to reference at any time. Figure 8 shows the Guide $\mathrm{Me}-$ Technical Tools interface on the 2030 Districts website. 


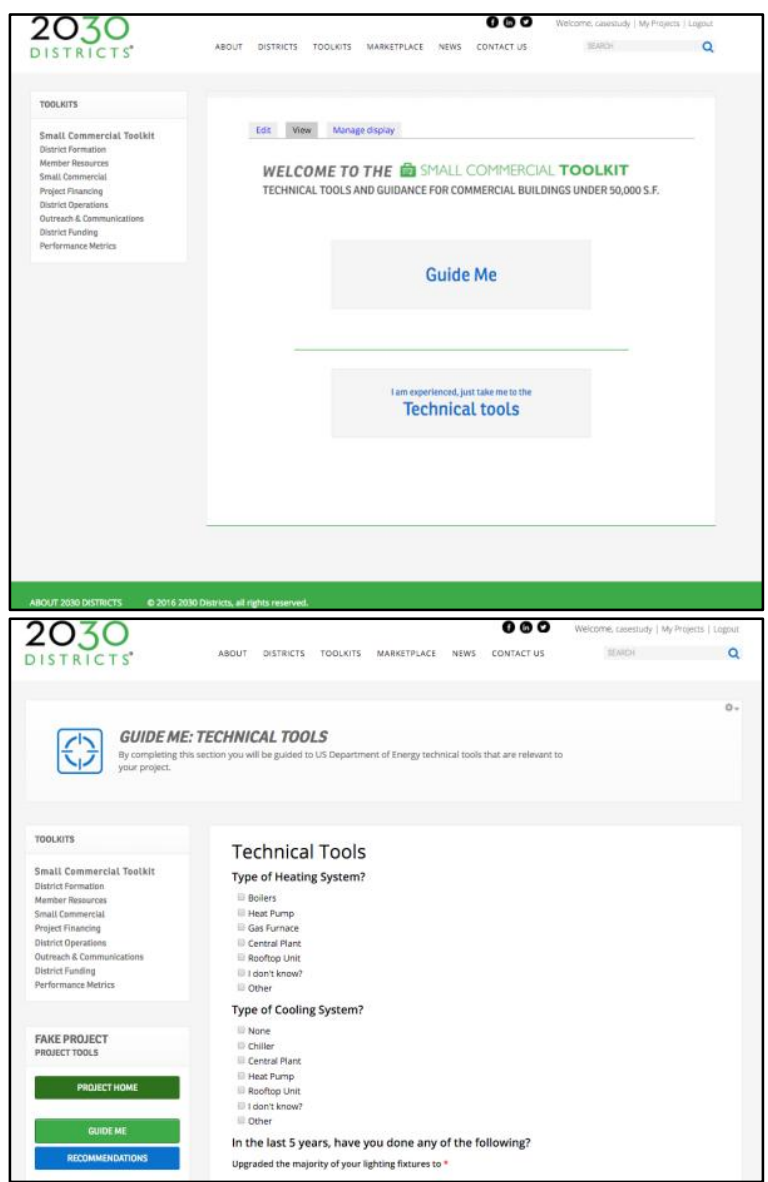

Figure 8: Guide Me - Technical Tools process

In addition to the Small Commercial Toolkit Guide Me process, there is also a separate Small Commercial Toolkit Tutorial that includes videos on how to set up a project, use the Guide Me system, and use each technical tool. These videos walk the viewer through the process of using the website itself, with each video covering one part of the website and/or process the user may go through to complete a building assessment. The tutorial videos continue the idea of being as user-friendly as possible so small commercial building owners can successfully complete energy and energy cost reduction projects.

The same design principles used to create the case study template and library were used to create the toolkit - succinct, user-friendly, and visually appealing. With the Guide Me process and toolkit tutorials, users are able to find what case studies are similar to their own project, and what tools should be used to determine energy and energy cost savings. Everything is visually appealing - it is easy to read and use due to the simple, modern aesthetics.

\section{Discussion}

Recall the project's goal is to address barriers faced by the small commercial sector, namely lack of: 1) access to centralized, comprehensive, and consistent information about how to achieve energy targets, 2) reasonable achievable energy targets, 3) access to tools that measure buildings' progress towards targets, 4) financial incentives that make the reduction effort attractive, and 5) effective models of how disparate stakeholders can collaborate in commercial 
centers to reach targets. With the implementation of the case study template and library, stakeholders within the small commercial sector will be able to gain knowledge on real energy efficiency projects that other owners have pursued and reported, and also understand the possible energy savings associated with completing an energy efficiency project within their own building. The technical tools in the Small Commercial Toolkit work concurrently with the case study library to help small commercial stakeholders in 2030 Districts achieve 2030 District goals; both the tools and the library were designed as easy-to-use options for stakeholders that may not have the knowledge base, time, or money to complete an energy retrofit project without assistance. With the Demonstration Partners engaging key stakeholders in their Districts, and the Districts' achievable energy savings goals, stakeholders will be able to effectively reach energy goals for their building, and work together to reach energy goals for the District, all the while creating case studies that further the case for energy efficiency in the small commercial sector and encourage broader implementation of energy efficiency retrofit projects in this market.

\subsection{Longevity}

Following the funding period, the project team will have limited or no resources available to maintain the Small Commercial Toolkit. Thus, the team focused, from the outset, on developing a system that users can run autonomously. That is, in order to update the case study library and its associate search options, users will have to enter and tag case studies themselves. The project team set climate zone, building type, and fuel type as default tags for all case studies. An API also supports automatic transfer of tags from other databases. The case study library will continue to include case studies from other databases, and it will grow as new projects create case studies on the web portal. Since the Guide Me process is a key component to the usefulness of the toolkit, and ensures stakeholders that lack energy efficiency knowledge can access the appropriate resources, the team ensured its functionality beyond the funding period.

Another issue in the future of the case study library is the selection of "related case studies" for users accessing resources via the Guide Me process. While the case study library includes less than thirty cases, it is unlikely that more than five case studies appear as "Related Case Studies" for a set of Guide Me inputs. However, as the case study library grows, so do the number of case studies that match Guide Me criteria. For instance, if there are a high number of marine climate zone case studies, and a Guide Me user inputs a project zip code within that climate zone, the Guide Me process would need to filter which five case studies should be recommended to the user. To address this issue, and promote a self-sustaining web portal, the project team opted to show the "first five" case studies meeting the user's inputs into the Guide Me process and provide a link to "More Case Studies." However, the team anticipates that many users will select building systems of interest during the Guide Me process, and that selection should narrow the number of "related case studies" considerably.

\subsection{Lessons Learned}

The project team corresponded with case study users and implementers throughout the Small Commercial Toolkit development process. Users indicated the importance of succinct and visual information, which led the project team to develop a two-page case study template, approximately one-quarter of which is devoted to graphics. While Demonstration Partners responded positively to the template, and expressed interest in using case studies in the template format from the library in their own decision-making processes, the process of developing case studies from Demonstration Partner projects illuminated the following lessons about the template: 
- Information about decision criteria can compel owners, but it is not easy to collect for future case studies: Demonstration Partners expressed interest in including this information in the case study template and were interested in understanding decision criteria for those projects that were originally included in the case study library. However, this data proved the most challenging to collect when documenting Demonstration Partner projects, as those stakeholders that created case studies may or may not have access to the decision makers for the retrofit project.

- Contractors will likely develop case studies: The authors developed the case study template to persuade owners to conduct energy retrofits in their small commercial buildings. However, the pilot projects suggest that it is contractors that have a business interest in creating a case study. This poses a challenge in data collection, as contractors involved in the retrofit project often have the energy data, but may lack access to data about the business case and recommendations to other building owners.

- The "free space" for technical tool output (top of page 2 of the case study template) is often left blank: To date, case study creators have not opted to include technical tool output in their case studies. Rather, most opt to leave the space at the top of page 2 blank. The authors recommend that District leaders promote inclusion of technical tool output in the open space on the template. Alternatively, District leaders could suggest branding information for the 2030 District be included in all case studies.

- Data collection beyond the "Required Information" to generate a project on the web portal is challenging: The case studies draw project data automatically from data that users input into the 2030 District web portal. This ensures that all case studies include "Project Information." However, a complete case study requires more data than is required to create a project on the web portal. Collecting this additional data can be challenging, particularly for those pieces of information that may be "lost" by the time the retrofit project is complete (when most projects create a case study). In particular, users may struggle to recall those retrofit measures that were not selected and the reasons for not selecting them.

\section{Conclusion}

Creating the Small Commercial Toolkit for the 2030 Districts addresses key energy efficiency issues within the small commercial sector that must be solved in order to meet energy reduction goals set by Architecture 2030. Designing the case study template and library with small commercial building stakeholders in mind meant modern aesthetics mixed with user-friendly searching capabilities, and a Guide Me process. With user-friendliness in mind, stakeholders with less energy-efficient buildings knowledge or resources can complete building assessments, gain financial knowledge, and research existing case studies similar to their own potential $\operatorname{project}(\mathrm{s})$.

\section{Acknowledgements}

This work was funded by an award from the U.S. Department of Energy's FOA 0000829, "Better Buildings - Commercial Energy Efficiency Solutions," specifically, the "Small Commercial 2030 District Program and Toolkit" project led by the Lawrence Berkeley National Laboratory. Any opinions, findings, conclusions, or recommendations expressed in this paper are those of the writers and do not necessarily reflect the views of the Lawrence Berkeley National Laboratory or the United States Department of Energy. 


\section{References}

Langner, Rois, Bob Hendron, and Shanti Pless. Industry Research and Recommendations for Small Buildings and Small Portfolios. Rep. no. NREL/TP-5500-57776. Golden, CO: National Renewable Energy Laboratory, 2013. Print.

Thornton, BA, W. Wang, Y. Huang, MD Lane, and B. Liu. "50\% Energy Savings for Small Office Buildings." (n.d.): n. pag. Technical Reports. Pacific Northwest National Laboratory, Apr. 2010. Web.

1. US DOE, Buildings Energy Data Book 2010, Washington, DC: U.S. Department of Energy

2. US DOE. Energy Efficiency Trends in Residential and Commercial Buildings. 2008 [cited 201613 Apr]; Available from: http://apps 1.eere.energy.gov/buildings/publications/pdfs/corporate/bt_stateindustry.pdf.

3. National Trust for Historic Preservation, Realizing the Energy Efficiency Potential of Small Buildings, P.G. Lab, Editor 2013, National Trust for Historic Preservation Preservation Green Lab: Washington DC. 66 pp.

4. 2030 Districts. About 2030 Districts. 2015 [cited 201519 Feb]; Available from: http://WWW.2030districts.org/about2030-districts.

5. US DOE, Advanced Energy Retrofit Guide: Office Buildings, 2011, United States Department of Energy: Washington, DC. 199 pp.

6. Langner, R., B. Hendron, S. Pless, M. Huppert, and R. Cochrane, Industry Research and Recommendations for Small Buildings and Small Portfolios, 2013, National Renewable Energy Laboratory: Golden, CO. 53 pp.

7. Architecture 2030. About Us. 2016 [cited 201614 Apr]; Available from: http://architecture2030.org/about/.

8. Architecture 2030. Why the Building Sector? 2016 [cited 201614 Apr]; Available from: http://architecture2030.org/buildings_problem_why/.

9. 2030 Districts. The 2030 Districts Network. 2016 [cited 201614 Apr]; Available from: http://wWw.2030districts.org/districts.

10. US EPA. ENERGY STAR Certification for Your Building. 2016 [cited 201614 Apr]; Available from: https://www.energystar.gov/buildings/facility-owners-and-managers/existing-buildings/earnrecognition/energy-star-certification.

11. New Buildings Institute (NBI). Case Studies. 2016 [cited 201610 Apr]; Available from: http://newbuildings.org/casestudies/.

12. Architecture 2030. Case Studies. 2016 [cited 201610 Apr]; Available from: http://www.2030districts.org/pittsburgh/case-studies.

13. Architecture 2030. 2030 Palette. 2016 [cited 201610 Apr]; Available from: http://blog.2030palette.org/category/casestudies/.

14. RMI. Case Studies. Retrofit Depot 2016 [cited 201610 Apr]; Available from: http://wWw.rmi.org/retrofit_depot_get_connected_true_retrofit_stories

15. US DOE. Commercial Buildings Resource Database. 2016 [cited 201610 Apr]; Available from: https://buildingdata.energy.gov/cbrd/. 